\title{
Operasjon eller trening for pasienter med kroniske ryggsmerter?
}

\section{Kognitiv intervensjon og trening gir like gode langtidsresultater som avstivningsoperasjon for pasienter med kroniske korsryggssmerter og redusert skivehøyde.}

Antallet avstivningsoperasjoner for behandling av kroniske ryggsmerter og degenerative forandringer i mellomvirvelskivene har nærmest eksplodert de siste 20 årene. Korttidsresultater har ikke vist effekt av slik operasjon sammenliknet med et strukturert behandlingsopplegg basert på kognitiv intervensjon og trening.

I min doktoravhandling har jeg undersøkt pasienter randomisert til enten avstivningsoperasjon eller kognitiv intervensjon og trening 7-11 år etter inklusjon. Det var ikke forskjell mellom de to gruppene når det gjaldt smertereduksjon, egenvurdert funksjon, engstelse for fysisk aktivitet, emosjonelt stress eller muskelstyrke. Begge grupper var bedre enn før behandlingen. Muskelstyrken var økt, til tross for at aktiv muskelstørrelse var redusert. Flere opererte pasienter brukte smertestillende medikamenter og var ute av arbeid, likevel rapporterte flere av de opererte at de var fornøyd med behandlingen. Det er hevdet at avstivning fører til ytterligere reduksjon av skivehøyde og nye smerter. Dette er en av de viktigste årsakene til at pasienter blir operert på nytt. I vår studie var skivehøyden redusert hos både opererte og ikke-opererte. Det var ikke samsvar mellom redusert skivehøyde og pasientenes plager.

Samlet tyder resultatene på at dagens praksis bør endres. Forventningene til effekt av avstivningssoperasjon svarer for de fleste ikke til resultatene. Strukturerte behandlingsmetoder basert på kognitiv intervensjon og trening bør prioriteres i større grad enn avstivningsoperasjon.

Anne Froholdt

annefroholdt@hotmail.no

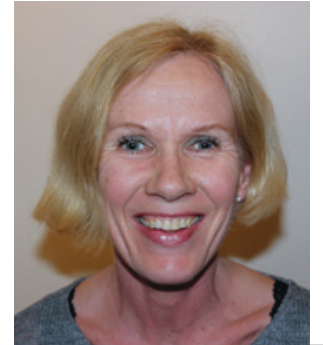

Anne Froholdt Foto: Privat

Disputas

Anne Froholdt disputerte for ph.d graden ved Universitetet i Oslo 6.2. 2014. Tittelen på avhandlingen er Long-term follow-up of chronic low back pain patients randomized to lumbar fusion or cognitive intervention and exercises.

\section{Kirurgi med skiveprotese i ryggen eller tverrfaglig rehabilitering?}

\section{Kirurgi med skiveprotese er kostnadseffektivt, men tverrfaglig rehabilitering bør være førstevalget ved degenerativ skivesykdom.}

Fjerning av mellomvirvelskive og innsetting av skiveprotese er en relativt ny kirurgisk teknikk for pasienter med ryggsmerter og degenerativ skivesykdom. Denne studien er den første der man har sammenliknet skiveprotese og et ikke-kirurgisk behandlingsalternativ.

I en multisenterstudie ble 173 pasienter randomisert til enten kirurgi med innsetting av skiveprotese eller tverrfaglig rehabilitering. Pasientene ble fulgt i to år. Studien viste at kirurgi ga signifikant flere kvalitetsjusterte leveår sammenliknet med rehabilitering. Kirurgi var dyrere enn rehabilitering når det gjaldt sykehuskostnader, det var imidlertid ingen signifikant forskjell i totalkostnader (sykehuskostnader pluss oppfølgingskostnader) i toårsperioden. I avhandlingen konkluderer vi derfor med at kirurgi med skive- protese er kostnadseffektivt. Tverrfaglig rehabilitering ga også signifikant bedring i livskvalitet - kirurgi med innsetting av skiveprotese kan ha potensielt alvorlige komplikasjoner. Vår anbefaling er derfor å prøve tverrfaglig rehabilitering først

Resultatene bør legge føringer for behandlingen av ryggpasienter både i Norge og internasjonalt. Studien er en av de første i Norge der man har vurdert kirurgi mot et ikke-kirurgisk behandlingsopplegg i en kostnad-nytte-analyse som følger QALYmodellen. Den kan dermed være en premissleverandør for beslutningstakere i helsevesenet når det gjelder prioriteringer på tvers av diagnosegrupper.

Lars Gunnar Johnsen

lars.gunnar.johnsen@stolav.no

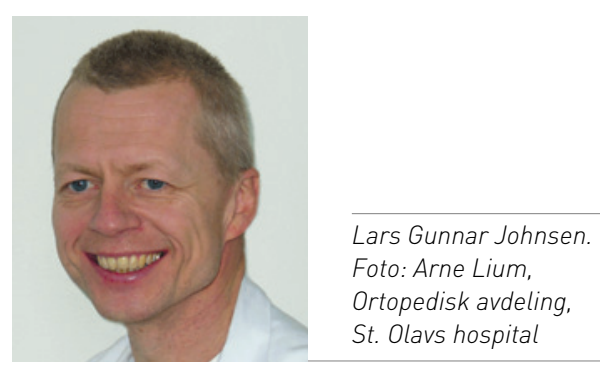

Disputas

Lars Gunnar Johnsen disputerte for ph.d.-graden ved Norges teknisk-naturvitenskapelige universitet 7.3. 2014. Tittelen på avhandlingen er Surgery with total disc replacement compared to rehabilitation in patients with chronic low back pain and degenerative disc disease. Clinical, health economical and biomechanical perspectives 